\title{
A Comparative Analysis of Surface Areas and Ratio of the Cervical Spinal Cord and the Vertebral Canal at the Same Levels Via MRI on Healthy Individuals
}

\author{
Análisis Comparativo de las Áreas de Superficie y Proporción de la Médula Espinal Cervical \\ y el Canal Vertebral en los Mismos Niveles Via Resonancia Magnética en Individuos Sanos
}

\author{
Fatma Duman*; Taner Ziylan**; Demet Kıresi***; Aynur Emine Cicekcibasi"*; \\ Mustafa Büyükmumcu** \& Tolga Duman****
}

DUMAN, F.; ZIYLAN, T.; KIRESI, D.; CICEKCIBASI, A. E.; BÜYÜKMUMCU, M. \& DUMAN, T. A Comparative analysis of surface areas and ratio of the cervical spinal cord and the vertebral canal at the same levels via MRI on healthy individuals. Int. J. Morphol., 32(4):1171-1178, 2014.

SUMMARY: The determination of the normal values of the cross-sectional surface areas and ratios of the vertebral canal and the spinal cord on the healthy individuals is of great importance with regards to the fact that it provides convenience for the doctors to make correct pathological diagnosis because of the most suitable treatment. In this study, it has been aimed to determine the respective ratios between the vertebral canal and the spinal cord via measuring their cross-sectional surface areas at the C3-C6 vertebra levels. The study has been implemented on the Magnetic Resonance Images (MRI) of the cervical vertebral column from healthy individuals at the Department of Radiology, Meram Faculty of Medicine, Necmettin Erbakan University. The study has been applied to 67 (50 female-17 male) individuals whose ages varied between 14 and 59 and these individuals have been divided into two groups as below and over 40 years of age. During the cervical MRI examination, axial and sagittal images have been evaluated and measurements have been made on the non-pathological axial images. The vertebral canal and the spinal cord surface areas have been calculated in square millimeters at the C3-C6 levels. Also, we calculated the ratio between the spinal cord surface area and the vertebral canal surface area. The obtained data has been transferred on the computer and statistical analysis has been implemented via SPSS package program (for Windows, 15.0). The summary of the data has been stated as Mean \pm SD. It has also been compared with regard to sex and age groups (below and over 40 years of age) using the Student t-test. The relationship between parameters has been evaluated by means of Pearson correlation test. No significant discrepancy $(\mathrm{P}>0.05)$ has been determined between the male and the female subjects in terms of the vertebral canal and spinal cord surface area values. On the other hand, at the C4, C5 and C6 levels, a significant discrepancy $(\mathrm{P}<0.05)$ has been observed between male and female subjects in terms of the ratio of spinal cord surface to the vertebral canal surface, stating that the male have it larger than the female. A positive correlation $(\mathrm{P}<0.01)$ between the surface area and ratio data of both sexes has been determined. We believe that the results of this study will be useful for the fields of neurology, neurosurgery and physical therapy and rehabilitation, particularly in evaluating spinal atrophy.

KEY WORDS: Cervical; Vertebral canal; Spinal cord; Area; Ratio.

\section{INTRODUCTION}

The structural changes occur in fractures, congenital anomalies, deformities and disk hernias related to vertebral column or tumoral and cystic formations related to spinal cord and surrounding tissue or diseases such as multiple sclerosis, stenosis, and myelopathy related to both the vertebral canal and the spinal cord. Therefore, anatomic measurements in evaluating spinal cord pathologies are essential.
Cervical vertebral column consists of five intervertebral disks and seven vertebra which are located between the chest and the head, protecting important parts such as the spinal cord, spinal nerve roots and vertebral arteries as well as supporting the head and allowing the head's movements in every possible plane (Güvençeft et al., 2001; DePalma \& Slipman, 2006).

\footnotetext{
* Department of Physiotherapy and Rehabilitation, High School of Physical Therapy and Rehabilitation, Mustafa Kemal University, Hatay, Turkey.

** Department of Anatomy, Meram Faculty of Medicine, Necmettin Erbakan University, Konya, Turkey.

*** Department of Radiology, Meram Faculty of Medicine, Necmettin Erbakan University, Konya, Turkey.

***** Özel Defne Hastanesi, Hatay, Turkey.
} 
The $1^{\text {st }}, 2 \mathrm{nd}$ and the $7^{\text {th }}$ cervical vertebrae are different than the others. The remaining four vertebrae are similar to each other. The $3^{\text {rd }}, 4$ th and $5^{\text {th }}$ cervical vertebrae are almost identical and although the $6^{\text {th }}$ one is of typical structure in terms of general features, it still has minor discrepancies that are specific (Soames, 1995; Güvençeft et al.).

The cross-sectional surface area of the cervical spinal cord is approximately $80 \mathrm{~mm}^{2}$ in normal adults. The anteroposterior diameter of the spinal canal between C3$\mathrm{C} 7$ is $17 \pm 5 \mathrm{~mm}$ and the diameter of cervical spinal cord between $\mathrm{C} 1-\mathrm{C} 7$ is approximately $10 \mathrm{~mm}(8.5-11.5 \mathrm{~mm})$. The spinal cord in a normal cervical vertebra fills $2 / 3$ of the spinal canal between $\mathrm{C} 1-\mathrm{C} 3$ and 1/2 between C4-C7 (Harrop et al., 2007).

A number of methods have been employed to measure the spinal cord cross-sectional surface area. One of the methods is manually making a chart of the high-resolution axial images. With this method, however, scanning errors reaching up to 6\% have been reported (Losseff et al., 1996). Losseff et al. have reported errors related to repetition of the measurements. Aside from the errors caused by the human interactions, it has also been reported that the inability in safely determining the anatomical boundary points has also been a major cause for the said errors. Via automatic and semi-automatic techniques, they have limited their studies with a small part of cervical spinal cord at the $2^{\text {nd }}$ cervical vertebra (C2) level. It has also been stated that for an accurate measurement, high resolution magnetic resonance images can be used to determine cervical spinal cord cross-sectional surface area by means of drawing out the anatomical boundary points (Tench et al., 2005).

Magnetic Resonance Imaging (MRI) is used to measure spinal atrophy in many diseases including mainly multiple sclerosis (MS), dementia and Alzheimer's. The recent developments in the MRI technology have made it possible for the spinal cord to be routinely scanned. These developments have also promoted the development of the renewable image analysis procedures in order to measure spinal cord crosssectional surface area or volume (Tench et al.).

Different studies related to spinal cord and vertebral canal can be found in the literature. Perese \& Fracasso (1959) have measured the spinal cord transvers diameter on $30 \mathrm{ca}-$ ses; Nordqvist (1964) has measured spatium subarachnoideum and spinal cord diameters on 101 cases which consisted of a variety of age groups; Hinck et al. (1966) have measured normal vertebral canal transvers diameters on children and the adults. Evangelou et al. (2005) have studied the diversity of spinal cord cross-sectional surface area in multiple sclerosis in terms of age and gender.
Yanase et al. (2006) have studied the cervical spinal cord volume on MRI in order to determine its relevance with height, weight, age and sex.

As it can be observed in the studies specified above, diameter, surface area and volume of both spinal cord and vertebral canal have individually been measured and yet, the two have never been examined nor their respective ratios been measured together. It is essential these examinations and measurements to be implemented on healthy subjects to provide convenience for the doctors in applying accurate pathological diagnosis. In this study, it is aimed to determine how much surface the cervical spinal cord occupy inside the vertebral canal measuring and proportioning the cervical spinal cord and vertebral canal surface areas on MRI via boundary point determination method.

\section{MATERIAL AND METHOD}

This study has been implemented on the Magnetic Resonance Imaging (MRI) of the cervical vertebral column from healthy individuals at the Department of Radiology, Meram Faculty of Medicine, Necmettin Erbakan University. The MRI images with non-pathological categorization of the cases which were suspected cervical spinal disc herniation have been examined. The material has been selected meticulously. The cases which had no previous cervical trauma, operation, anatomical variation or congenital anomaly have also been included in the study. The pathological cases that alter the bone density like osteoporosis or the spinal cord width and volume like multiple sclerosis have not been included in the study. Following the radiological examination, the MRI of the cases that were completely normal and no pathology related to bone and spinal cord have been selected. The study has been scheduled for 67 (50 female, 17 male) individuals which were between 14 and 59 ages and these individuals divided into two groups as below and over 40 years of age.

A $1.5 \mathrm{~T}$ (tesla) Siemens Magnetom Symphony (Germany) device has been used for the Magnetic Resonance Imaging and cervical coil has been scanned. The axial and sagittal images that were obtained from the routine cervical MRI have been examined and the measurements were made on the axial images of non-pathological normal subjects.

The images have been transferred to the work station (Leonardo, Siemens Medical Solutions). Initially, each cervical vertebra has been located on the sagittal MRI scans of each subject. Then, the vertebral canal and spinal cord surface areas have been calculated in millimeter units using the soft- 
ware (syngommwp VE30A, syngo VE32B) on the workstation via $\mathrm{C} 3, \mathrm{C} 4, \mathrm{C} 5$ and $\mathrm{C} 6$ cervical vertebra axial images (Figs. 1 and 2).

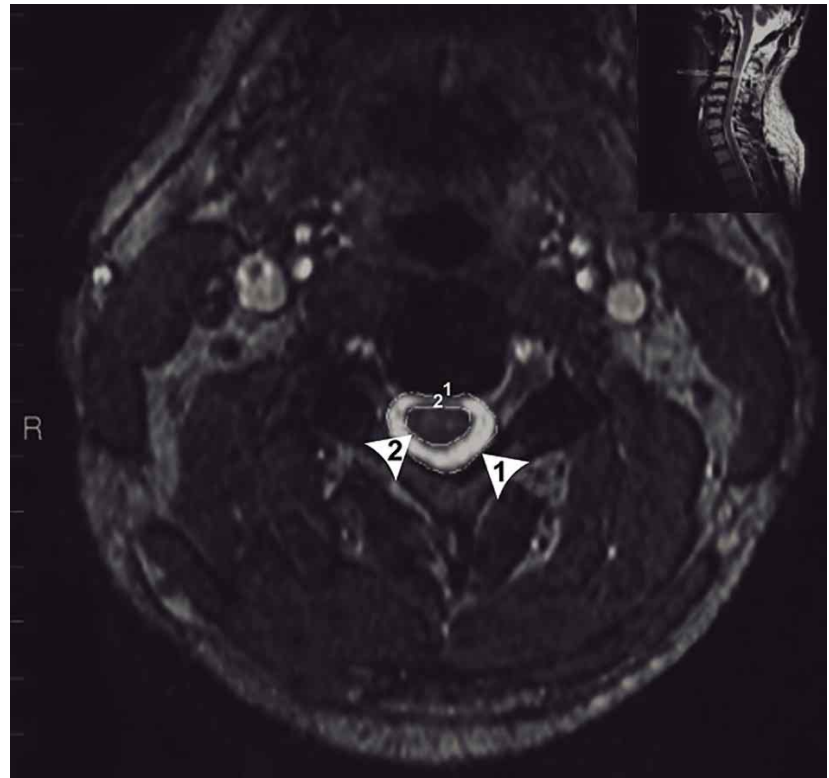

Fig. 1. Calculation of vertebral canal and spinal cord surface areas on the $\mathrm{C} 3$ level axial images. Arrow 1= Vertebral canal surface area. Arrow $2=$ Spinal cord surface area.

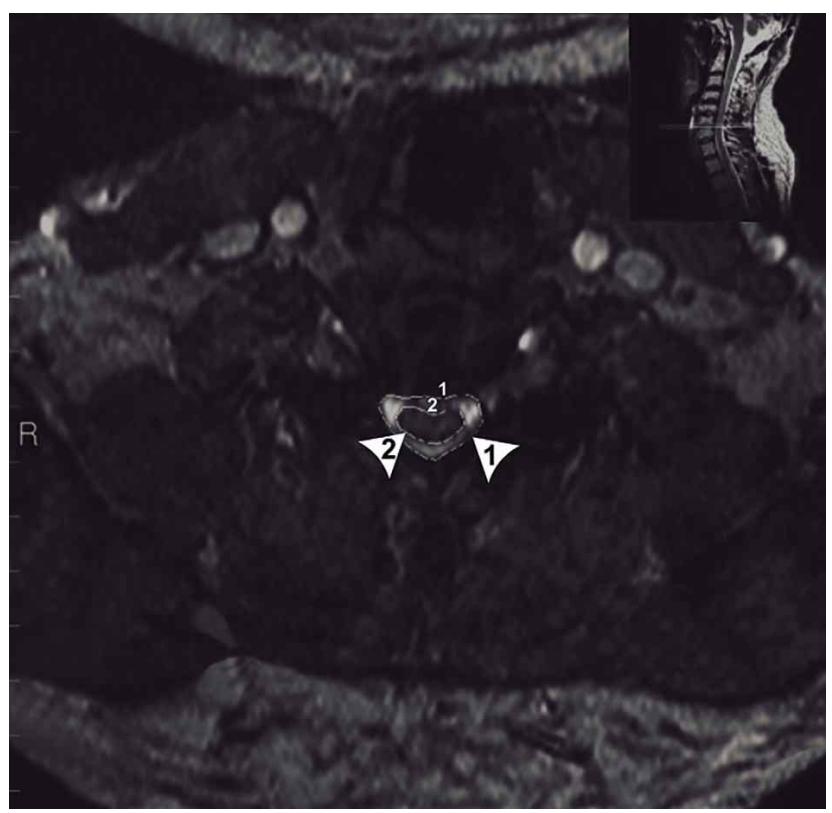

Fig. 2. Calculation of vertebral canal and spinal cord surface areas on the C6 level axial images. Arrow 1= Vertebral canal surface area. Arrow $2=$ Spinal cord surface area.

The obtained data has been transferred on the computer and statistical analysis has been implemented via SPSS package program (for Windows, 15.0). Out of these calculated surface area values, the vertebral canal surface area value has been divided by the spinal cord in order to determine their ratio to each other. The summary of the data has been stated as Mean \pm SD. The data has also been compared in terms of gender and age groups (over and below 40 years of age) via Student t-test. The relationship between parameters has been evaluated via the Pearson correlation test.

\section{RESULTS}

No significant discrepancy has been determined between the male and the female subjects in terms of the vertebral canal surface area values $(\mathrm{P}>0.05)$. However, it has been observed that the vertebral canal surface areas at the C4, C5 and C6 levels on the female subjects were larger than the male subjects, whereas it was larger on the male subjects at the $\mathrm{C} 3$ level. The vertebral canal surface area at the C3 level was measured as $251.59 \pm 58.49 \mathrm{~mm}^{2}$ on the male subjects and $248.54 \pm 26.96 \mathrm{~mm}^{2}$ on the female subjects; at the $\mathrm{C} 4$ level, it was measured as $236.41 \pm 59.95 \mathrm{~mm}^{2}$ on the male subjects and $247.34 \pm 27.90 \mathrm{~mm}^{2}$ on the female subjects; at the C5 level, it was measured as 244.18 \pm 53.20 $\mathrm{mm}^{2}$ on the male subjects and $248.86 \pm 27.83 \mathrm{~mm}^{2}$ on the female subjects; at the C6 level, $239.35 \pm 42.44 \mathrm{~mm}^{2}$ on the male subjects and $243.02 \pm 23.69 \mathrm{~mm}^{2}$ on the female subjects (Table I).

It has been determined that no discrepancies were observed between male and the female subjects with regards to the spinal cord surface area values in the whole cervical levels $(\mathrm{P}<0.05)$. However, it was also observed that the measured values were higher in the male subjects than the female subjects. The spinal cord surface at C3 level was measured as $101.00 \pm 14.11 \mathrm{~mm}^{2}$ on the male subjects and $95.22 \pm 11.15 \mathrm{~mm}^{2}$ on the female subjects; at the C4 level, it was measured as $106.29 \pm 14.16 \mathrm{~mm}^{2}$ on the male subjects and $102.28 \pm 11.36 \mathrm{~mm}^{2}$ on the female subjects; at the C5 level, it was measured as $110.47 \pm 15.47 \mathrm{~mm}^{2}$ on the male subjects and $103.58 \pm 11.83 \mathrm{~mm}^{2}$ on the female subjects; and at the C6 level the values indicated $104.18 \pm 19.20 \mathrm{~mm}^{2}$ for the male subjects whereas it showed $95.44 \pm 13.78 \mathrm{~mm}^{2}$ for the female subjects (Table I).

Significant discrepancies have been determined in the ratio of spinal cord surface area value to the vertebral canal surface area value at the C4, C5 and C6 levels $(\mathrm{P}<0.05)$ and it has been observed to be larger in the male subjects than the female ones. C3 level was measured as $0.41 \pm 0.06$ $\mathrm{mm}^{2}$ on the male subjects and $0.38 \pm 0.05 \mathrm{~mm}^{2}$ on the female subjects; at the $\mathrm{C} 4$ level, it was measured as $0.46 \pm 0.08 \mathrm{~mm}^{2}$ 
Table I. The distribution of spinal cord and vertebral canal surface areas and the ratio between spinal cord and vertebral canal surface areas in terms of sex $\left(\right.$ Mean $\left.\pm \mathrm{SD}, \mathrm{mm}^{2}\right)$.

\begin{tabular}{llccl}
\hline & & $\begin{array}{c}\text { Male } \\
(\text { Mean } \pm \text { SS })\end{array}$ & $\begin{array}{c}\text { Female } \\
(\text { Mean } \pm \text { SS })\end{array}$ & P \\
\hline C3 & Cord & $101.00 \pm 14.11$ & $95.22 \pm 11.15$ & 0.090 \\
& Canal & $251.59 \pm 58.49$ & $248.54 \pm 26.96$ & 0.772 \\
& Ratio & $0.41 \pm 0.06$ & $0.38 \pm 0.05$ & 0.074 \\
C4 & Cord & $106.29 \pm 14.16$ & $102.28 \pm 11.36$ & 0.242 \\
& Canal & $236.41 \pm 59.95$ & $247.34 \pm 27.90$ & 0.314 \\
& Ratio & $0.46 \pm 0.08$ & $0.42 \pm 0.06$ & $0.019^{*}$ \\
C5 & Cord & $110.47 \pm 15.47$ & $103.58 \pm 11.83$ & 0.060 \\
& Canal & $244.18 \pm 53.20$ & $248.86 \pm 27.83$ & 0.643 \\
& Ratio & $0.46 \pm 0.07$ & $0.42 \pm 0.06$ & $0.017 *$ \\
C6 & Cord & $104.18 \pm 19.20$ & $95.44 \pm 13.78$ & $0.049 *$ \\
& Canal & $239.35 \pm 42.44$ & $243.02 \pm 23.69$ & 0.659 \\
& Ratio & $0.44 \pm 0.57$ & $0.40 \pm 0.06$ & $0.018^{*}$ \\
\hline
\end{tabular}

Table II. The correlation of spinal cord and vertebral canal surface areas and the ratio of spinal cord surface area to vertebral canal surface area on the male subjects (Mean $\pm \mathrm{SD}, \mathrm{mm}^{2}$ ).

\begin{tabular}{llccc}
\hline C3 & Cord & $\begin{array}{c}\text { Group 1: under 40 } \\
\text { years of age } \\
\text { (Average } \pm \text { SS) }\end{array}$ & $\begin{array}{c}\text { Group 2: over 40 } \\
\text { years of age } \\
\text { (Ortalama } \pm \text { SS })\end{array}$ & P \\
& Canal & $95.94 \pm 12.77$ & $98.45 \pm 10.55$ & 0.442 \\
& Ratio & $0.40 \pm 0.05$ & $252.90 \pm 30.17$ & 0.609 \\
C4 & Cord & $102.43 \pm 13.51$ & $0.40 \pm 0.05$ & 0.918 \\
& Canal & $242.98 \pm 42.09$ & $105.35 \pm 7.98$ & 0.371 \\
& Ratio & $0.43 \pm 0.08$ & $248.30 \pm 28.34$ & 0.607 \\
C5 & Cord & $103.72 \pm 13.49$ & $0.46 \pm 0.06$ & 0.982 \\
& Canal & $246.66 \pm 39.25$ & $250.05 \pm 25.61$ & 0.724 \\
& Ratio & $0.43 \pm 0.07$ & $0.43 \pm 0.05$ & 0.519 \\
C6 & Cord & $95.23 \pm 15.38$ & $103.35 \pm 15.99$ & 0.055 \\
& Canal & $241.62 \pm 30.17$ & $243.20 \pm 27.69$ & 0.841 \\
& Ratio & $0.40 \pm 0.07$ & $0.43 \pm 0.05$ & 0.069 \\
\hline
\end{tabular}

on the male subjects and $0.42 \pm 0.06 \mathrm{~mm}^{2}$ on the female subjects; at the C5 level, it was measured as $0.46 \pm 0.07 \mathrm{~mm}^{2}$ on the male subjects and $0.42 \pm 0.06 \mathrm{~mm}^{2}$ on the female subjects; at the C6 level, the values for the male subjects were $0.44 \pm 0.57 \mathrm{~mm}^{2}$ and $0.40 \pm 0.06 \mathrm{~mm}^{2}$ for the female subjects (Table I).

The relation between spinal cord and vertebral canal surface areas and the ratio on male and female subjects has been demonstrated in Table II and Table III. A positive correlation between the data has been determined $(\mathrm{P}>0.01)$.

In any of the levels, there were no discrepancies between the two age groups in terms of the obtained data $(\mathrm{P}>0.05)$. However, it has also been observed that the surface area data increased proportional to age (Table IV).

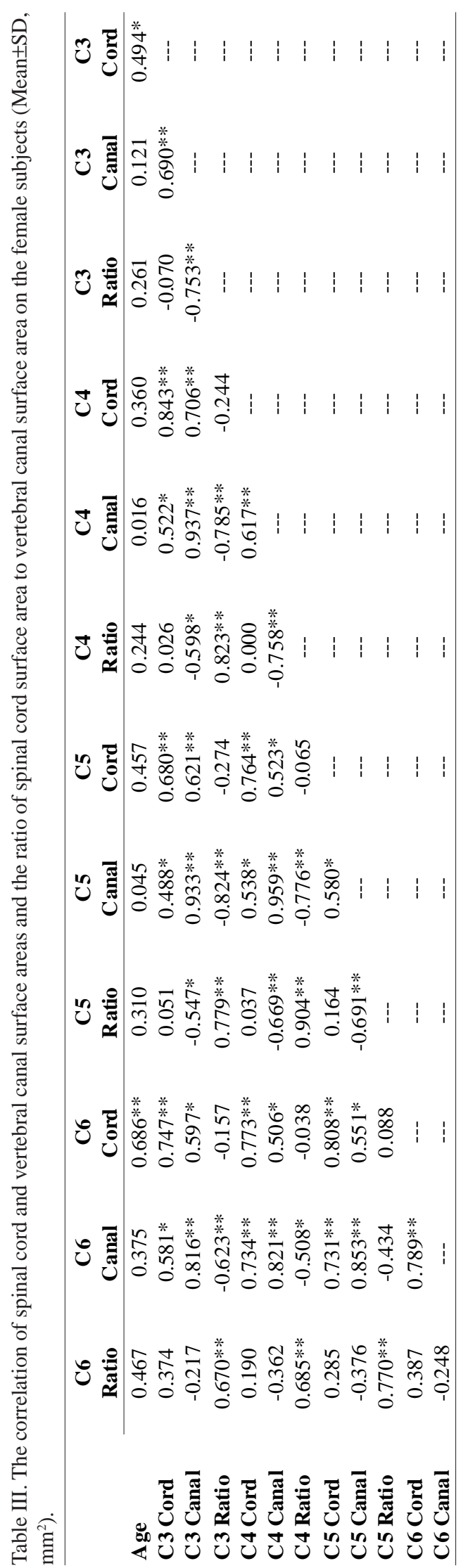




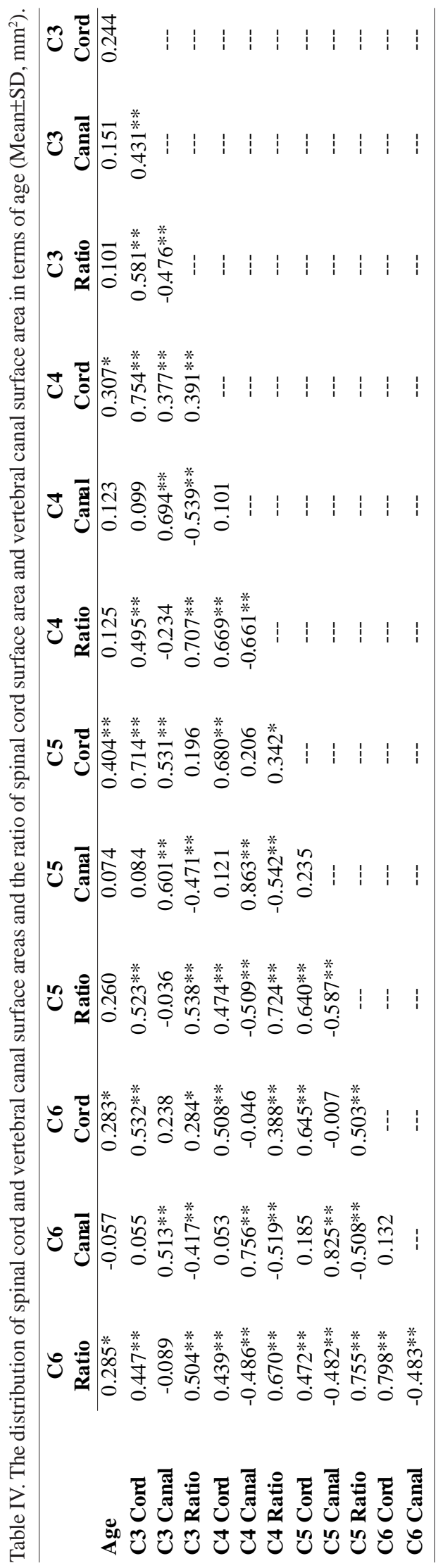

\section{DISCUSSION}

It is observed that the studies regarding spinal cord and vertebral canal measurements are old ones. Malinowsky (1910) has studied the structural relationship between the spinal cord and vertebral canal on frozen cadavers and measured the diameter of spinal cord on certain levels. He stated in his research that the thickness of spinal cord on the cervical part was significantly larger. According to Malinowsky, the cervical intumescentia extends from $\mathrm{C} 2$ vertebra to T4 vertebra. The most significant one is at the C4 vertebra level and is $10-11 \mathrm{~mm} \times 14-17 \mathrm{~mm}$. He also stated that vertebral canal expanded in parallel with the spinal cord and the narrowest part was at thoracic level.

In his study on frozen cadavers, Eliott (1945) has measured the sagittal and transverse diameters of spinal cord. He has used the plane between the segments of C5-C6, T6$\mathrm{T} 7$ and L5-S1 of the spinal cord. He has obtained the maximum values of the expansions for cervical and lumbar surface areas (cervical and lumbar intumescentia) and the minimum values for the thoracic surface. Elliott has stated that the previous studies have not been able to present sufficient statistical findings. Therefore, he fixated the cadavers with formalin with a percentage of 5\%,10\% and $15 \%$. It has been re-measured the sections on these levels after 1, 7 and 30 days and found that the maximum alteration depending on formalin being less than $0.5 \mathrm{~mm}$. He has reported that the minimal diameter measurement of spinal cord at the thoracic surface was $8.0 \times 6.5 \mathrm{~mm}$. It has also been reported that the spinal cord diameter was no relations to factors such as age, sex, weight or race.

Kameyama et al., (1994) have investigated the correlation between the transvers surface area and diameter of the spinal cord at $\mathrm{C} 7$ level and age, height, weight and brain weight. They have also observed significant individual changes about the spinal cord size during their measurements on the $\mathrm{C} 2-\mathrm{T} 1$ segments of 14 cadavers. They have reported that the transverse spinal cord surface area at C7 segment has demonstrated changes varying from 33.3 $\mathrm{mm}^{2}$ to $74.0 \mathrm{~mm}^{2}$ (an average of $49.6 \pm 7.4 \mathrm{~mm}^{2}$ ). Although a significant correlation between the size of spinal cord and the brain weight has been noted, a less significant correlation has been determined with age and weight.

It was observed to be higher than that of Kameyama et al., (at C7 level) of our values (at C6 level). In our study, the spinal cord surface area at C6 level of the male subjects was measured as $104.18 \pm 19.20 \mathrm{~mm}^{2}$ and $95.44 \pm 13.78 \mathrm{~mm}^{2}$ of the female subjects. However, Kameyama et al., have stated that the transvers spinal cord surface area at C7 
segment varied from $33.3 \mathrm{~mm}^{2}$ to $74.0 \mathrm{~mm}^{2}$ (an average of $\left.49.6 \pm 7.4 \mathrm{~mm}^{2}\right)$. We believed that the difference between the data arising from the diversity of materials and methodology. In this study, the measurements have been implemented on healthy subjects with radiological equipment via the help of computers whereas Kameyama et al., have worked manually on cadavers. The error margin in the manual measurement and shrinkage of tissue in the spinal cord due to formaldehyde may be the reason for the above-specified difference.

It has been reported that the differences of spinal cord transverse diameter were important determining the cordotomy incision depth (Perese \& Fracasso). In the study about spatium subarachnoiedeum and spinal cord diameter implemented on 101 cases, the measurements of myelography and spinal cord preparations have been compared. In 31 of these cases, the spinal cord has been dissected from vertebral canal and the extracted spinal cord have been fixed by a $10 \%$ formalin for about 1-2 months and then their anatomical boundaries have been marked by lead bands less than $1 \mathrm{~cm}$ in width, taking their sagittal and transverse sectional radiographies. The spinal cord findings from myelography have been compared with the direct $\mathrm{x}$ ray results that were obtained from the fixated material. The similarity between the sagittal diameters has been determined. The transverse diameter, however, are $1 \mathrm{~mm}$ smaller in myelography (except T12 level) than the direct $\mathrm{x}$-ray results (Nordqvist).

It has been known for years that the brain and the spinal cord have undergone atrophy in multiple sclerosis. However, special attention is paid to the issue for accurate measurement of tissue loss and examination of it. The advances in the MRI and image analysis techniques have facilitated this process and the determination of atrophy through measurements has been used to evaluate the effects of the treatment (Bakshi et al., 2005).

The involvement of cervical level is highly significant in the development of physical inadequacy on the patients with multiple sclerosis. Zivadinov et al. (2008), have applied measurements of three different cervical spinal cord levels on 66 patients with multiple sclerosis whose ages varied between 18 and 70 and confirmed atrophy. Evangelou et al. have studied on 55 patients with multiple sclerosis whose ages varied between 25 and 83 and investigated the discrepancies of the spinal cord sectional surface area in terms of age, sex and spinal cord level. It has been determined that the spinal cord sectional surface area in patients with multiple sclerosis was smaller in top-bottom cervical and top thoracic levels than those of the normal individuals.

Cervical spondylotic myelopathy is one of the most common diseases that affect the spinal cord of the patients who are over 50 years of age (Ross, 1995). This pathology usually appears in the later years and clandestinely causes paraparesis or quadriparesis. The initial myelopathy symptoms are not apparent and this causes delays in diagnosis. Although the development process of myelopathy is not completely known, the spinal stenosis and the compression of the spinal cord occur with a degenerative or spondylitic process on the spinal canal. Myelopathy symptoms usually do not vary and the prevention of the disease can be possible with surgery. The vertebral column and the cervical spinal cord images need to be accurate and a reliable evaluation are essential for a regularly surgical planning (Ross).

Due to the fact that the tissue contrast is superior to computed tomography, the ligaments, intervertebral disks and soft tissues can be evaluated better via MRI. ArlienSoborg et al. (1993) have conducted prospective research via myelo BT and MRI regarding vertebral canal on patients with myelopathy. They have reported that myelography is essential in the evaluation of vertebral canal whereas it is insufficient in terms of minor intramedullary alterations. It has also been stated that the MRI is an excellent technique in imaging vertebral canal and spinal cord (Arlien-Soborg).

Blease Graham et al. (2001), have studied on 21 patients with cervical myelopathy whose ages varied between 27 and 78 as they were in supine neutral and prone extension position and determined the alteration of cervical spinal cord and subarachnoid space on sectional surface areas. They have indicated that there has been a decrease in the surface area of the sectional spinal cord and subarachnoid space on the damaged spondylotic cervical levels in the prone position when compared to the supine position.

Personal discrepancies have also been observed on the spinal cord surface area. Yanase et al., have studied on 90 healthy subjects and examined the volume of the cervical spinal cord as well as its relationship with height, weight, age and sex through MRI scans. They have determined that the cervical spinal cord volume was greater in male subject than that of the female; decreased through age; and there was a direct proportion with height and weight.

Tierney et al. (2002), have measured the diameters of spinal cord, vertebral canal and vertebra corpus at $\mathrm{C} 2-\mathrm{C} 7$ vertebra levels on 24 healthy male subjects. They have calculated the Torg ratio by dividing the vertebral canal diameter by vertebra corpus. The Torg ratio is used to determine spinal stenosis. Aside from, they have also employed another method in determining the spinal stenosis by extracting the spinal cord diameter from vertebral canal, 
getting at the remaining space (spatium subarachnoiedum). It has been determined that there is a positive correlation between the average space value and the Torg ratio $(\mathrm{P}<0.01)$. Consequently, it has been reported that the spatium subarachnoiedum value can be considered as a better marker than the Torg ratio for stenosis (Tierney et al.; Karabulut \& Karabulut, 2007).

In this study, the surface areas of cervical spinal cord and vertebral canal on the intervertebral disks of same levels have been measured and rationed. Their relations with age and sex have been researched. It was observed that the obtained ratio by dividing the spinal cord surface area by vertebral canal surface area exhibited a significant difference between male and female subjects at the C4, C5 and C6 levels $(\mathrm{P}<0.05)$ and that it was larger in male subjects than female. Although no significant differences were noted between the male and female subjects regarding the area values at all levels, it was determined that the spinal cord surface area was greater in the male subjects than the female.
Whereas the vertebral canal surface area values were greater in the female subjects at the C4, C5 and C6 levels, it was measured greater in the male subjects at the $\mathrm{C} 3$ level.

There has not been any difference between the two age groups for the vertebral canal surface area, the spinal cord surface area and the ratio values at all vertebral levels $(\mathrm{P}>0.05)$. However, it has also been noted that the surface area values increased with age. A positive correlation was observed between the spinal cord and vertebral canal surface areas and ratio values in both male and female subjects $(\mathrm{P}<0.01)$.

In this study, the surface area of cervical spinal cord and vertebral canal on the same level intervertebral disks have been measured and compared and their relations with age and sex have been researched. It was considered to be useful not only spinal cord surface area but also vertebral canal area to evaluate the atrophy in cases with myelopathy, particularly.

DUMAN, F.; ZIYLAN, T.; KIRESI, D.; CICEKCIBASI, A. E.; BÜYÜKMUMCU, M. \& DUMAN, T. Análisis comparativo de las áreas de superficie y proporción de la médula espinal cervical y el canal vertebral en los mismos niveles via resonancia magnética en individuos sanos. Int. J. Morphol., 32(4):1171-1178, 2014.

RESUMEN: La determinación de los valores normales de las áreas de superficie de la sección transversal y las proporciones del canal vertebral de la médula espinal en los individuos sanos es de gran importancia para los médicos, para realizar un diagnóstico patológico correcto y un tratamiento más adecuado. Este estudio se llevó a cabo para determinar las respectivas proporciones entre el canal vertebral y la médula espinal a través de la medición transversal de áreas de superficie, entre los niveles de las vértebras C3-C6. El estudio se realizó através de imágenes de resonancia magnética (IRM) de la columna vertebral cervical de individuos sanos en el Departamento de Radiología, de la Facultad de Medicina de Meram, Universidad de Necmettin Erbakan. En el estudio participaron 67 sujetos (50 mujeres, 17 hombres) entre 14 y 59 años de edad. Los sujetos fueron divididos en dos grupos, menores y mayores de 40 años de edad. Durante el examen de IRM cervical, se evaluaron imágenes axiales y sagitales, estas mediciones se realizaron en las imágenes axiales no patológicas. El canal vertebral y las áreas de superficie de la médula espinal fueron calculados en milímetros cuadrados entre los niveles C3-C6. Además, se calculó el cociente entre el área de superficie de la médula espinal y la superficie del canal vertebral. Los datos obtenidos de superficie del canal vertebral, fueron transferidos al equipo y el análisis estadístico se implementó a través del programa SPSS (para Windows, 15.0). El resumen de los datos fue declarado como Media \pm DE. También fueron comparados grupos entre ambos sexos y por edad (menores y mayores de 40 años de edad) através de la prueba t de Student. La relación entre los parámetros fue evaluada mediante la prueba de correlación de Pearson. No se observó discrepancia significativa $(\mathrm{P}>0,05)$ entre hombres y mujeres en términos del canal vertebral, y los valores de la columna vertebral de la zona de superficie dorsal. Por otro lado, a nivel C4, C5 y C6, se observó una discrepancia significativa $(\mathrm{P}<0,05)$ entre hombres y mujeres, en términos de la proporción de la superficie de la médula espinal y la superficie del canal vertebral, indicando que fue mayor en los hombres. Se determinó una correlación positiva $(\mathrm{P}<0,01)$ entre el área de superficie y los datos de proporción de ambos sexos. Creemos que los resultados de este estudio serán de utilidad en las áreas de la neurología, neurocirugía, como también en terapia física y rehabilitación, en particular en la evaluación de la atrofia espinal.

\section{PALABRAS CLAVE: Cervical; Vertebral Canal Ver; Spinal cord; Area; Proporción.}

\section{REFERENCES}

Arlien-Soborg, P.; Kjaer, L. \& Praestholm, J. Myelography, CT, and MRI of the spinal canal in patients with myelopathy: a prospective study. Acta Neurol. Scand., 87(2):95-102, 1993.

Bakshi, R.; Dandamudi, V. S.; Neema, M.; De, C. \& Bermel, R. A. Measurement of brain and spinal cord atrophy by magnetic resonance imaging as a tool to monitor multiple sclerosis. $J$. Neuroimaging, 15(4 Suppl.):30S-45S, 2005.

Blease Graham, C. 3rd.; Wippold, F. J. 2nd.; Bae, K. T.; Pilgram, T. K.; Shaibani, A. \& Kido, D. K. Comparison of CT myelography performed in the prone and supine positions in 
the detection of cervical spinal stenosis. Clin. Radiol., 56(1):35$9,2001$.

DePalma, M. J. \& Slipman, C. W. Treatment of common neck problems. In: Braddom, R. (Ed.). Physical medicine and rehabilitation. 3rd ed. Philadelphia, Elsevier, 2006. pp.797824.

Elliott, H. C. Cross-sectional diameters and areas of the human spinal cord. Anat. Rec., 93:287-93, 1945.

Evangelou, N.; DeLuca, G. C.; Owens, T. \& Esiri, M. M. Pathological study of spinal cord atrophy in multiple sclerosis suggests limited role of local lesions. Brain, 128(Pt.1):29-34, 2005 .

Güvençeft, M.; Karatosun, V. \& Korman, E. Omurganın Anatomisi. Kemik Yap1. J. Turk. Spinal Surg., 12(1-2):44-6, 2001.

Harrop, J. S.; Hanna, A.; Silva, M. T. \& Sharan, A. Neurological manifestations of cervical spondylosis: an overview of signs, symptoms, and pathophysiology. Neurosurgery, 60(1 Suppl. 1):S14-20, 2007.

Hinck, V. C.; Clark, W. M. Jr. \& Hopkins, C. E. Normal interpediculate distances (minimum and maximum) in children and adults. Am. J. Roentgenol. Radium Ther. Nucl. Med., 97(1):141-53, 1966.

Kameyama, T.; Hashizume, Y.; Ando, T. \& Takahashi, A. Morphometry of the normal cadaveric cervical spinal cord. Spine (Phila. Pa. 1976), 19(18):2077-81, 1994.

Karabulut, Ö. \& Karabulut, Z. The variations of Torg ratio with gender in patients with neck pain. Dicle Tip Dergisi, 34(4):2724, 2007.

Losseff, N. A.; Webb, S. L.; O'Riordan, J. I.; Page, R.; Wang, L.; Barker, G. J.; Tofts, P. S.; McDonald, W. I.; Miller, D. H. \& Thompson, A. J. Spinal cord atrophy and disability in multiple sclerosis. A new reproducible and sensitive MRI method with potential to monitor disease progression. Brain, 119(Pt. 3):7018, 1996.

Malinowsky, K. Massbestimmungen am Wirbelkanal: Dage der einzelnen Teile und sonstige Veraltnisse desselben. Arch. F. Anat. Physiol. U. Wissenschaftl. Med., 8:249, 1910.

Nordqvist, L. The sagittal diameter of the spinal cord and subarachnoid space in different age groups. A roentgenographic post-mortem study. Acta Radiol. Diagn. (Stockh.), Suppl. 227:1-96, 1964.

Perese, D. M. \& Fracasso, J. E. Anatomical considerations in surgery of the spinal cord: a study of vessels and measurements of the cord. J. Neurosurg., 16(3):314-25, 1959.

Ross, J. S. Myelopathy. Neuroimaging Clin. N. Am., 5(3):367-84, 1995.
Soames, R. W. Skeletal system. In: Williams, P. L. (Ed.). Gray's Anatomy. 38th ed. New York, Churchill Livingstone, 1995.

Tench, C. R.; Morgan, P. S. \& Constantinescu, C. S. Measurement of cervical spinal cord cross-sectional area by MRI using edge detection and partial volume correction. J. Magn. Reson. Imaging., 21(3):197-203, 2005.

Tierney, R. T.; Maldjian, C.; Mattacola, C. G.; Straub, S. J. \& Sitler, M. R. Cervical Spine Stenosis Measures in Normal Subjects. J. Athl. Train., 37(2):190-3, 2002.

Yanase, M.; Matsuyama, Y.; Hirose, K.; Takagi, H.; Yamada, M.; Iwata, H. \& Ishiguro, N. Measurement of the cervical spinal cord volume on MRI. J. Spinal Disord. Tech., 19(2):125-9, 2006.

Zivadinov, R.; Banas, A. C.; Yella, V.; Abdelrahman, N.; WeinstockGuttman, B. \& Dwyer, M. G. Comparison of three different methods for measurement of cervical cord atrophy in multiple sclerosis. AJNR Am. J. Neuroradiol., 29(2):319-25, 2008.

Correspondence to:

Aynur Emine Cicekcibasi, MD.

Department of Anatomy

Meram Faculty of Medicine

Necmettin Erbakan University

42080 Meram

Konya

TURKEY

Email: aynurcicekcibasi@yahoo.com.tr

Received: 31-01-2014

Accepted: 11-07-2014 